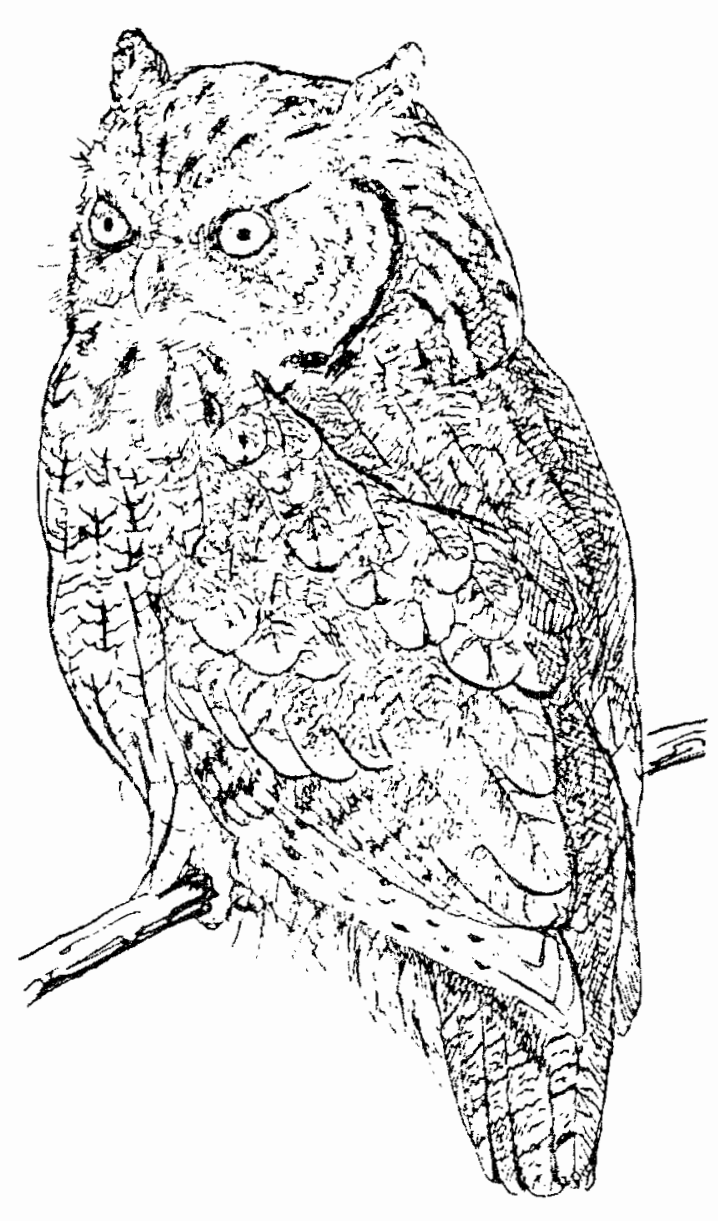

Barry Xent Macksy inimeI Protectlon Ingtitute (API) -

\section{THE GENTLE WAY}

Once some people were shamans Who could enter the forest And let the forest enter them.

Once those who were shamans Could become what they beheld And return with wisdor.

Once all people shared this wisdom. of their Earth mother and creature-kin Knowing the world in many ways.

Once people knew themselves As eagle, bear, wolf, and whale And saw the whole with shaman eyes.

They knew the shaman's way Was through the heart of all, All souls abiding in communion.

MICHAEL W. FOX

\section{CIVIL DISARMAMENT}

\author{
TONY SMITH \\ Toronto, Ontario, Canada
}

Before we can liberate both the animals and ourselves from the tyranny of gun love, we must be liberated from the halfway house of gun control.

The rifle is the weapon with which millions of animals are killed in America every year--for amusement. Nor is there scarcely a hunted species today whose numbers have not been drastically reduced in part by rifle hunters. Rifles are also frequently used in killings of people..

Gun control critics often defer to sportsmen and the National Rifle Association, acknowledging them to be "law-abiding citizens." However, that people appear to be law-abiding is not a sufficient basis for allowing them to keep firearms. Guns can be stolen, and even hunters can fall prey to mental illness.

America needs gun abolition, not gun control. All guns not made for the purposes of military or civil defense should be banned. School children should be given both a practical and a humane understanding of the evils in hunting (for example, we wonder if killing animals isn't more common among criminals than among the populace in general). of course, the police and military would disarm only when and insofar as the purposes of civil disamament had been served. Through this process, Americans would learn that civil disarmament poses no more threat to freedoms worth saving than did the abolition of slavery.

Every time we hear of someone who is shot by a gun that would have been unavailable if sport firearms were abolished, we are given further reason for denouncing the shooting of animals for pleasure.

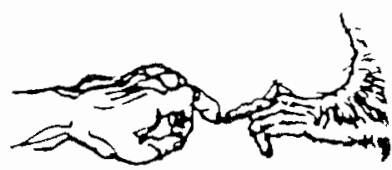

